\title{
Understanding the Benefit of Satisfaction Toward Mobile Shopping Applications
}

\author{
Putri Aprilia Berlian \\ Department Management, \\ Faculty of Economics \& Business, Universitas Indonesia \\ Depok, Indonesia \\ putriberlian@gmail.com
}

\author{
Tengku Ezni Balqiah* \\ Department Management, \\ Faculty of Economics \& Business, Universitas Indonesia \\ Depok, Indonesia \\ tengku.ezni@ui.ac.id
}

\begin{abstract}
The growth of information and communication technology, especially, the digital age, enhance the popularity of mobile applications. This study aims to analyze the important of satisfaction in mobile shopping applications. Shopee is a mobile shopping application based in Southeast Asia, an e-commerce platform that connects both buyers and sellers in transaction and do online shopping experience, even in smartphones. Refers to technology acceptance model (TAM) Theory, and this study examine other antecedents: enjoyment, innovativeness, and risk as predictor satisfaction. Further, the role of satisfaction in increasing repurchase intention, and reduce price sensitivity. Eight hypotheses were analyzed by structural equation modeling approach, using 734 respondents that were collected by purposive sampling. The result demonstrated that except innovativeness, all antecedents could drive satisfaction. Furthermore, satisfaction influences influences price sensitivity directly, and indirectly through repurchase intention. Based on thd finding, online marketers must concern toward some risk in order to decrease price sensitivity on mobile shopping applications.
\end{abstract}

Keywords-e-commerce, satisfaction, mobile shopping application, repurchase intention, price sensitivity.

\section{INTRODUCTION}

In 2017, internet users in Indonesia were increased almost $51 \%$ [1-2]. This surge has driven the rapid growth of online shopping. The value of sales from online shopping in Indonesia soared by $470 \%$ between 2012 and 2017 [3]. Further, Indonesia overtook Singapore and Thailand in 2014 as the largest e-commerce market in ASEAN with a total value of US\$1.1 billion [4].

The development of e-commerce in Indonesia runs parallel with the growth of mobile commerce. This condition post Indonesia as the most rapidly expansion mobile commerce market in the world [5]. Based on research conducted by Better Than Cash Alliance, it was revealed that the mobile commerce market in Indonesia grew by $155 \%$ in 2016 [5]. Further, 33\% of Internet users in Indonesia make online purchases via mobile devices [2].
The popularity of mobile shopping application, attract some e-commerce to use this application that can be apply in smartphone both Android and iOS operating system [6]. Shopee is a mobile shopping application from Singapore that entered Indonesia in 2015 [7]. Through smartphone Shopee arrange an online marketplace that connect both sellers and buyers to perform online shopping on mobile basis [7]. According to Bisnis.com [8], Indonesia is an important market where the total number of Shopee users is fifteen million - the largest figure compared to six other countries. Currently, Shopee has reached consumers in more than 515 regencies throughout Indonesia with a total transaction value of $40 \%$ [8].

Mobile shopping via phone applications is a new paradigm which continues to grow and has a great potential in the business world [9]. Based on the previous explanations, it can be concluded that the development of mobile shopping application reaches one of its highest incidents in Asia. However, the effectiveness of driving repurchase intention remains a question because it is proven that e-commerce sales in Indonesia only contribute to 0.7 percent of its total retail trade [4].

Thus, marketers must concern to how to develop positive attitude and behavioral responses in mobile shopping applications. By doing so, a company can increase its mobile shopping application effectiveness through increased sales, profit maximization, and the creation of new opportunities for its customers: current and potential [9]. Congruently, the technology acceptance model (TAM) explains the adoption of a new information system [10]. TAM can be assist to understand the advantage of mobile shopping applications to create customer support. This attract some researchers to study how to protend customers reponses to mobile commerce. These studies reveals, in shopping context, various factors as the drivers of intention to use smartphones $[9,10,11]$. It depends on risk, usefulness, ease of use, enjoyment and personal innovativeness [9]. As well, satisfaction has also proven to be an important variable as customer response in using mobile commerce [11]. 


\section{LiterATURE REVIEW AND HYPOTHESIS DEVELOPMENT}

\section{A. Technology Acceptance Model}

TAM explain about adoption and intention to adopt a new technology in information system [10]. The objectives of TAM are to describe some antecedents that could drive technology acceptance, explaining user behavior across enduser computing technologies and user populations, while at the same time being both economical and theoretically correct [10]. TAM states that intention is the important precursor of actual adoption an information system, whereby it depend on attitudes.

TAM explain how Perceived Usefulness (PU) and Perceived Easy of Use (PEU) influence attitude toward technology adoption. Compare to attitude model, the nonattitude model also explain variations as much as the model attitude in the field of wireless technology such as mobile commerce [12]. In addition, research conducted by Teo [13] proved that when analyzing the intention to use a techology, there were no mediation effect of attitudes in developing behavior. Likewise, there was no significant difference in value variation explained by attitude compare to non-attitude.

\section{B. Satisfaction}

TAM is used extensively to explain the acceptance of information systems and mobile commerce specifically [11]. However, it is important to add other variables that are related to consumers' cognitive response that occur after purchase. Thus, a satisfaction variable is added to the model. Locke [14] defines satisfaction as a positive emotional phase of one's work performance. Oliver [15] further defines satisfaction as a state of psychological or emotional aspects formed by the cognitive evaluations of expectations compare to actual performance. Both definitions involve psychological or affective conditions formed by cognitive judgments or differences between expectations and actual performance [16]. Further, lower expectations and/or higher performance result in higher levels of individual confirmation, which lead to a positive influence on consumer's satisfaction, and vice versa [16].

\section{Repurchase Intention}

Repurchase intention is defined as the subjective likelihood of an individual buying products through the same mobile shopping applications in the future [17]. Furthermore, according to Wen et al [12], continuance of such intention, just like repurchase intention in a marketing context, is an individual's decision to repeat an action. Both continuance and repurchase intention are influenced by experience when making a purchase. Mobile shopping applications users are not only users of technology systems, but are also consumers. Understanding how to improve repurchase intention is critical to the development and success of mobile shopping application companies [12]. Therefore, this research is conducted to understand how to improve repurchase intentions in a mobile shopping application through influencing factors.

\section{Price Sensitivity}

According to Goldsmith, Kim, Flynn, and Kim [18], price sensitivity is a variable which exhibit individual differences. It indicates how buyers response to prices and price changes. The level of price sensitivity of each consumer varies based on each individual's characteristics, product or brand, credibility, incomes, and time differences [19]. Thus, this study aim to analyze customers' price sensitivity in mobile shopping applications [9].

\section{E. Perceived Risk}

The increasing level of Internet penetration makes consumers more concerned with various types of risks that may occur when conducting online transactions [20]. Perceived risk reflect uncertainty, probability of occurring an unexpected event when consume a product or service [21]. In service, Johnson, Sivadas, and Garbarino [22] examines the influence of risk toward customer satisfaction. Their finding exhibited that perceived risk influence customer satisfaction, negatively and significantly. If a customer's perceived risk when using mobile shopping application for shopping is considered to be low, it will increase his satisfaction in shopping through mobile shopping application, and vice versa.

$\mathrm{H}_{1}$ : In mobile shopping applications, perceived risk negatively influence satisfaction.

\section{F. Perceived Usefulness (PU)}

$\mathrm{PU}$ is a main variable in TAM which explains intention behaviors [10]. This variable refer to the belief about how using a technology can increase performance [10]. In this study, PU is described as the level where consumer believes that using a mobile shopping application for shopping can improve his shopping task performance [23].

The relationship between PU and satisfaction in mobile commerce context is examined by Agrebi and Jallais [11], Hung, Hwang, and Hsieh [24], and Yuan, Liu, Yao, and Liu [25]. In the context of e-commerce, PU positively influence satisfaction [26]. Individual expect something when they using a mobile phone to make purchases [11]. Thus, when a consumer considers that a mobile shopping application has a high usefulness for shopping activity, his satisfaction with the application will increase.

$\mathrm{H}_{2}$ : In mobile shopping applications, perceived usefulness positively influence satisfaction.

\section{G. Perceived Ease of Use (PEU)}

PEU denote as the level to which individuals expect that it does not require some big mental effort in using a system [10]. In their research, Agrebi and Jallais [11] examined the the influence of PEU toward satisfaction. Usually, individuals have some expectation before use a mobile shopping application. The study proves that PEU is one of the expectations of users that drive satisfaction [11]. Furthermore, in mobile shopping application, Natarajan et 
al. [9] revealed a positive relationship between PEU and satisfaction.

$\mathrm{H}_{3}$ : In mobile shopping applications, perceived easy of use positively influence satisfaction.

\section{H. Perceived Enjoyment}

Perceived enjoyment constitute the degree of pleasant when using computer, regardless of the consequences [10]. In mobile shopping application, perceived enjoyment reflect expectation of the user and the differences between their expectations and the real performance of the application which drive customer satisfaction [9]. Agrebi and Jallais [11] conducted a study which demonstrated the relationship between perceived enjoyment and satisfaction. The results show that perceived enjoyment is a driver of satisfaction in using mobile commerce. Thus, if consumers think that shopping via a mobile shopping application is "fun," then consumers will be satisfied with it.

$\mathrm{H}_{4}$ : In mobile shopping applications, perceived enjoyment positively influence satisfaction.

\section{Personal Innovativeness}

According to Rogers [27], personal innovativeness is the level of individual quickness in adopting new ideas compared to other members in a social system. The division of the adopters' levels is categorized into five groupings: (1) innovators, (2) early adopters, (3) early majority, (4) late majority, and (5) laggards [27]. In mobile commerce context, Hung et al. [24] exhibited how personal innovativeness influence satisfaction. Same result also demonstrated by Natarajan et al. [9] in the context of shopping applications, there is relationship between personal innovativeness with satisfaction. If consumers have a high level of innovativeness, it will increase consumer satisfaction with the application.

$\mathrm{H}_{5}$ : In mobile shopping applications, personal innovativeness positively influence satisfaction.

\section{J. Consequences of Satisfaction}

In their research, Wang and Liao [28] revealed that the higher the level of consumer's satisfaction, the higher the level of repurchase intention will be. Further, in research conducted by Agrebi and Jallais [11] in mobile shopping application, higher levels of consumer's satisfaction were shown to lead to higher intention to use. When performance comply with their expectations, it will lead to positive evaluation that promote to purchase it [9]. Thus, if consumers have high satisfaction with a mobile shopping application then they will tend to repurchase using the application in the future.

$\mathrm{H}_{6}$ : In mobile shopping applications, users satisfaction positively influence repurchase intention.

Generally, consumers measure their satisfaction toward the offering through perceived value of the price they have to pay and the costs they should incur when purchasing a product or service, comparing it with similar purchases [29]. If the price paid for a product or service is high, and the product obtained is not satisfactory, then consumers will become unwilling to repurchase in the same application [29].

In their research, Low et al. [29] demonstrated, when buying tangible, consumer's satisfaction will reduce price sensitivity. This outcome means that if consumers have high satisfaction with a mobile shopping application then they will have less price sensitivity to the application, and vice versa.

H7: In mobile shopping application, satisfaction negatively influence one's price sensitivity.

In his research, Munukka [30] analyzed price perceptions of mobile service users in order to examine the relationship between customer's willingness to purchase and price sensitivity. One's purchase intention is a measure of customer intention to conducted certain behaviors and it is corresponding to the construction of intention to use in TAM [9]. Furthermore, in studies conducted by Koppius, Speelman, Stulp, Verhoef, and Heck [31] and Park and Noh [32] a significant relationship between price sensitivity and purchase intention was revealed. A person who repeatedly uses a service in general will intensify trust in the technology, and reduce price sensitivity [9]. Thus, consumers who demonstrate some repurchase intention in a mobile

$\mathrm{H}_{8}$ : In mobile shopping application, repurchase negatively influence on the price sensitivity.

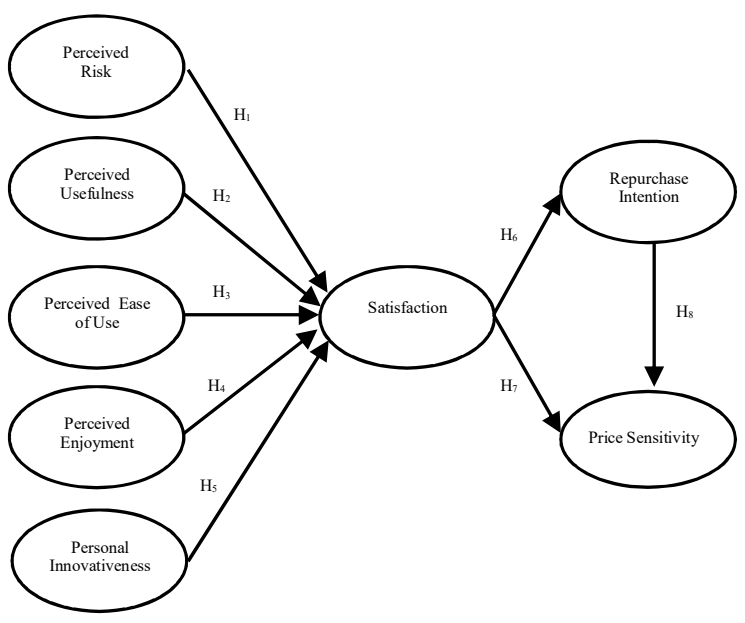

Fig. 1. Research Model

\section{RESEARCH METHOD}

Respondents are women and men, 15-34 years ols, who had bought in Shopee at least once in last six-month, and domiciled in Indonesia. Data were collected through online cross sectional survey. There were 37 items on the questionnaire (see Appendix), a seven-point Likert scale consist of five items pertaining to perceived risk [21], six items pertaining to PU [10], five items pertaining to PEU [10], three items pertaining to perceived enjoyment [33], five items pertaining to personal innovativeness [27], four items 
pertaining to satisfaction [14], four items pertaining to repurchase intention [34-35], and five items pertaining to price sensitivity [18].

Data were collected through an online questionnaire using Google forms, and there were 770 responses, of which 36 respondents were excluded because they did not meet the criteria. Thus, the total amount of data that are processed further is 734 . The sample mostly are women $(86 \%), 90 \%$ between 15 and 26 years old, 52\% graduated at least from diploma, 28\% were employees, and 56\% lived in Jakarta. More than $50 \%$ of respondents are customers of Shopee application for more than one-year, but only $27 \%$ use Shopee at least once a week. The survey also showed that the most popular products that respondents purchased were cosmetics products, because Shopee is a favorite online shopping destination for such items.

\section{RESULT AND ANALYSIS}

\section{A. Descriptive Statistics}

All variables were valid and reliable, with constructed reliability ranging from 0.77 to 0.94 , and standardized loading factors (SLF) ranging from 0.42 to 0.95 . Therefore, according to Malhotra [37] and Hair et al. [38], the whole group of indicators may be considered to have good reliability and validity, thus useful for further examination in this research. Using a structural equation modeling approach featuring one-tail $(\alpha=5 \%)$, as shown in Table I, only hypothesis 5 is rejected.

Perceived risk reflects consumer perceptions of uncertainty as well as negative consequences when using a technology [38]. In e-commerce, Tan, Chong, Loh, and Lin [39] suggest that technologies with unreliable security systems can lead to low levels of satisfaction and a desire to repurchase. Furthermore, Johnson et al. [22] state the consumers who are at a performance, doing a financial transaction, or facing time risk might lower their level of satisfaction. Thus in this study, researchers found out that if the risk in buying products in Shopee were considered low, it would increase consumer satisfaction.

TABLE I. DATA ANALYSIS RESUlT

\begin{tabular}{|c|l|c|c|c|}
\hline \multirow{2}{*}{ Hypothesis } & \multirow{2}{*}{$\begin{array}{c}\text { Independent } \\
\text { Variables }\end{array}$} & Satisfaction & $\begin{array}{c}\text { Repurchase } \\
\text { Intention }\end{array}$ & $\begin{array}{c}\text { Price } \\
\text { Sensitivity }\end{array}$ \\
\cline { 3 - 5 } & & Model 1 & Model 2 & Model 3 \\
\hline & Risk & $-0.08(-3.63)$ & & \\
\hline $\mathrm{H}_{1}$ & Usefulness & $0.19(4.12)$ & & \\
\hline $\mathrm{H}_{2}$ & Ease of Use & $0.10(2.98)$ & & \\
\hline $\mathrm{H}_{3}$ & Enjoyment & $0.63(13.60)$ & & \\
\hline $\mathrm{H}_{4}$ & $\begin{array}{l}\text { Personel } \\
\text { Innovativeness }\end{array}$ & $0.01(0.57)$ & & \\
\hline $\mathrm{H}_{5}$ & Satisfaction & & $0.56(10.19)$ & \\
\hline $\mathrm{H}_{6}$ & Satisfaction & & & $-0.13(-1.70)$ \\
\hline $\mathrm{H}_{7}$ & $\begin{array}{l}\text { Repurchase } \\
\text { Intention }\end{array}$ & & & $0.14(1.78)$ \\
\hline $\mathrm{H}_{8}$ & \multicolumn{3}{|l}{} \\
\hline Sig=5\% (one-tailed) &
\end{tabular}

Based on the results of hypothesis testing, there is a positive influence of $\mathrm{PU}$ toward satisfaction $\left(\mathrm{H}_{2}\right.$ is supported). This finding is in accordance with Natarajan et al. [9] that exhibit a significant positive relationship between the two variables in India. Furthermore, using mobile shopping in smartphone, also exhibit significant positive relationship between PU and satisfaction [11]. Conversely, in this research, perceived risk influence satisfaction negatively $\left(\mathrm{H}_{1}\right.$ is supported). This finding is in accordance with Natarajan et al. [9] who showed a significant negative relationship between risk and customer satisfaction in India. Furthermore, Yuan et al. [38] indicated a significant negative relationship between the two variables was likewise shown in the context of smartphone use for mobile shopping.

According to Agrebi and Jallais [11] when consumers use smartphones to make purchases, they will have expectations and are able to make purchases when they do not have access to a physical store or computer. Therefore, PU can have a positive impact on satisfaction. In this study the researcher concludes that if usage level in Shopee is considered high, it will increase consumer satisfaction toward Shopee.

Likewise, there is a direct positive influence between PEU and satisfaction $\left(\mathrm{H}_{3}\right.$ is supported). This result is in line with the previous research conducted by Natarajan et al. [9] and Agrebi and Jallais[11], indicating a significant positive influence between the two variables. Furthermore, referring to Aldás-Manzano et.al [40], PEU positively influence attitude in the context of adoption of Internet shopping.

Seen from the highest SLF value of the perceived ease of use, PEU4 with the value of 0.89 , indicates that consumers consider an application to have a high perceieved ease of use rate if they believe that it is easy to use. Furthermore, judging from the highest SLF value of satisfaction variable, SAT1 and SAT3 with the value of 0.91 , indicates that consumers will assume an application has a high level of satisfaction if they are satisfied and happy with their decision to shop in the mobile shopping application. If both are linked, when the consumers think if the mobile shopping application is easy to use, then consumers will feel satisfied and content with the choice to shop mobily.

Based on the result of hypothesis testing, there is a significant positive influence of perceived enjoyment toward satisfaction $\left(\mathrm{H}_{4}\right.$ is supported). This is accordance with the research conducted by Natarajan et al. [9] and Agrebi and Jallais [11], in which a significant positive relationship was found between the two variables. When mobile shopping application was perceived high enjoyment, it will increased the level of consumer satisfaction toward the mobile shopping application.

As with PU and PEU, perceived enjoyment may be similarly considered to be expectations that indicate satisfaction. The discrepancy between expectations and real performance can lead to satisfaction of using mobile shopping applications [9]. For that, mobile shopping applications that are considered fun to use will provide even greater satisfaction for consumers [11]. 
In this study, there is an insignificant relationship between personal innovativeness and satisfaction $\left(\mathrm{H}_{5}\right.$ is not supported). This outcome is not in line with Natarajan et al. [9], who indicated a significant relationship between the two variables. Nevertheless, this finding is in line with Hung et al. [24] who indicated a non-significant relationship between personal innovativeness and attitude.

Personal innovativeness denote how individual adopt technology especially information system [41]. It will assist marketers to identify and develop different strategy to influence them compare to others. The mean score of respondents' personel innovativeness is 4.42 (out of 7 Likert). This score exhibit the level of respondents' innovativeness slightly higher than neutral. It means respondents are not early adopters of technology. It could be explained why it can not influence their satisfaction.

Based on this hypothesis testing result, satisfaction may be concluded to have a significantly positive influence on repurchase intention ( $\mathrm{H}_{6}$ is supported). The finding is similar with the theory of TAM [10] which expressed that attitude influences behavioral intention. This result is also in line with research conducted by Natarajan, et al. [9] and Yuan et al. [38] that suggests siginifact and positive relationship between these two variables.

Consumers with high levels of satisfaction with a mobile shopping application will have a high repurchase intention and possibly a high likelihood of repurchase [24]. If consumers' expectations of shopping in mobile shopping applications can be met by the application, then evaluation of their experience when using the application can be a positive reason to shop using the application back in the future [11]. Based on the result of this study, researchers concluded that high levels of customer satisfaction will increase consumer repurchase intention with Shopee.

Further, result indicate satisfaction influence price sensitivity negatively $\left(\mathrm{H}_{7}\right.$ is supported). This outcome is in line with Natarajan et al. [9] who found a significant negative influence of satisfaction on price sensitivity. Furthermore, Low et al. [29] also showed a significant negative relationship on the two variables in the context of retail industry in Taiwan.

Consumers typically measure their level of satisfaction with a product or service by comparing the price they paid for it, and the costs incurred when purchasing similar items or with other customers making similar purchases [29]. If the price paid is expensive, but the product obtained is not satisfactory, then the consumer will assume that the purchase in unfair. Hence, consumers will be unwilling to make future purchases using the same mobile shopping application. Therefore, it can be concluded that if the consumer considers a purchase satisfactory, then the consumer will commit himself to it and become less price sensitive.

In this research, it is known that repurchase intention positively effect price sensitivity $\left(\mathrm{H}_{8}\right.$ is not supported). This finding is different to Natarajan et al. [9] where the study revealed that intention to use negatively influence price sensitivity. However, in his research, Koppius et al. [31] proves that continuance intention influence price sensitivity positively. Even though respondents tend to reuse, they still concern with the price change.

Price sensitivity could be affected by consumer activity in searching information about price, and do price comparison among various choice of products, services, or retailers. Thus, if consumers find it is easy to do a price comparison, their level of price sensitivity level may increased [30]. Furthermore, prices may also influence consumer behavior in an opportunistic way [30]. Promotion and discounts will appeal consumers, influence their interest and desire toward products and/or services. It is a marketing strategy to increase sales. When discounts are used regularly, it will boost fierce price competition in the market. In Indonesia, the growing of e-commerce stimulate increasing similar products' supply that drive intense price competition [42].

By mobile applications, customers consumers will be more easier to browse in an effort to find the product needed. The same product will be offered on different sites at different prices. As a result, consumers are able to search price information that lead them to compare prices more easily. This situation explain why repurchase intention actually ethere increase price sensitivity.

\section{CONCLUSION AND IMPLICATIONS}

The objective of this research was to analyze the repurchase intention and how it influence price sensitivity and satisfaction in mobile shopping applications utilization. This research replicates the research model from Natarajan et al. [9] which analyzed the antecedent and outcome of satisfaction in mobile shopping applications. The researchers modified the research model by substituting the intention to use variable with repurchase intention [17] [38] [40]. That modification was intended to gain a broader idea of factors that affect repurchase intention as indicate loyalty.

Based on analysis in the previous section, except innovativeness, other antecedent positively influence on satisfaction of a mobile shopping application. Further, satisfaction positively influence between repurchase intention and negatively influence price sensitivity. However, there are several results that differed with prior research. Researchers suspect that this variance is due to contextual differences in the country or its culture, and the study thus serves as the object of this research (Shopee) with Natarajan et al. [9].

Managerial suggestions that the researchers can provide are based on those findings. Mobile shopping application companies, especially Shopee, should minimize risk, such as risk related to performance, financial, time, security, social, and psychological risks. It is important to lure consumers shop in mobile shopping application. The researchers also suggest that Shopee and other mobile applications to develop features that can improve usability and simplify the shopping process in the application-from registration to payment process. Hence, mobile shopping application could fulfill consumer needs effectively and conveniently. Further, to 
increase consumer enjoyment, the researchers suggest that the company add colors and creative designs within the mobile shopping application to suit the tastes of consumers. Thus, Shopee may create and enhance consumer satisfaction, by improving factors that have been discussed. It is important because increasing consumer satisfaction, can enhance consumer's repurchase intention as well as detract consumer's price sensitivity. However, Shopee should still conduct sales promotion activities by providing discounts, vouchers, and so forth to compete with competitors in the midst of an environment of intense price competition in the e-commerce industry.

There are two limitations of this study. First, the research model was developed based on the concept of TAM. However, TAM is more appropriately used for potential users, where the users use a technology system for less than three months, while respondents of this study had already used Shopee application for six months or more. Second, it was assume there are only indirect effect of all antecedent toward repurchase intentions, that is through satisfaction toward mobile applications. It is highly suggested to broaden the scope and insert other variable as mediation, such as quality and attractiveness.

\section{REFERENCES}

[1] We Are Social. (2016). Digital in 2016 Report.

[2] We Are Social. (2017). Digital in 2017 Report.

[3] Euromonitor. (2018). Internet Retailing in Indonesia

[4] DBS Asian Insights (2015). E-Commerce In Asia: Bracing for Digital Disruption. Retrieved from: https://www.dbs.com.sg/vicke rs/en/research/insights/151103_insights_e_commerce_in_asia_bracin g_for_digital_disruption.page.

[5] Indonesia Investments. (2017). Indonesia is the World's Fatest Growing Mobile-Commerce Market. Retrieved from: https://ww w.indonesia-investments.com/id/business/business-columns/indonesia -is-the-world-s-fastest-growing-mobile-commerce-market/item7802.

[6] To The New. (2015). 6 online shopping apps Indonesians can't live without. Retrieved from: http://www.tothenew.com/blog/6-onlineshopping-apps-indonesians-cant-live-without/

[7] Daily Social. (2016). Pertumbuhan Tren Mobile Commerce di Indonesia Tinggi, tapi Belum Sedrastis Itu. Retrieved from: https://dailysocial.id/post/pertumbuhan-tren-mobile-commerce-diindonesia-tinggi-tapi-belum-sedrastis-itu.

[8] Bisnis (2017). Shopee Cetak Transaksi \$3 Miliar. Retrieved from: http://industri.bisnis.com/read/20170802/12/677421/shopee-cetaktransaksi-us3-miliar.

[9] Natarajan, T., Balasubramanian, S. A., Kasilingam, D. L. (2017). Understanding the intention to use mobile shopping applications and its influence on price sensitivity. Journal of Retailing and Consumer Services, 37, 8-22.

[10] Davis, F. D. (1989). Perceived usefulness, perceived ease of use, and user acceptance of information technology. MIS Quaterly, 13(3), 319340 .

[11] Agrebi, S., \& Jallais, J. (2015). Explain the intention to use smartphones for mobile shopping. Journal of Retailing and Consumer Services, 22, 16-23.

[12] Wen, C., Prybutok, V. R., \& Xu, C. (2011). An integrated model for customer online repurchase intention. Journal of Computer Information Systems, 52(1), 14-23.

[13] Teo, T. (2009). Is there an attitude problem? Reconsidering the role of attitude in the TAM. British Journal of Educational Technology, 40(6), 1139-1141.

[14] Locke, E. A. (1976). The nature and causes of job satisfaction. In M. D. Dunnette (Ed.), Handbook of industrial and organizational psychology (pp. 1297-1343). Chicago: Rand McNally.
[15] Oliver, R. L. (1981). Measurement and evaluation of satisfaction processes in retail settings. Journal of Retailing, 57(3), 25-48.

[16] Bhattacherjee, A. (2001). Understanding information systems continuance: an expectation-confirmation model. MIS Quarterly, 351-370.

[17] Chiu, C. M., Chang, C. C., Cheng, H. L., \& Fang, Y. H. (2009). Determinants of customer repurchase intention in online shopping. Online Information Review, 33(4), 761-784.

[18] Goldsmith, R. E., Kim, D., Flynn, L. R., \& Kim, W. M. (2005). Price sensitivity and innovativeness for fashion among Korean consumers. The Journal of Social Psychology, 145(5), 501-508.

[19] Erdem, T., Swait, J., \& Louviere, J. (2002). The impact of brand credibility on consumer price sensitivity. International Journal of Research in Marketing, 19(1), 1-19.

[20] Wu, J.-H., \& Wang, S.-C. (2005). What drives mobile commerce?: an empirical evaluation of the revised technology acceptance model. Journal of Information and Management, 42(5), 719-729.

[21] Featherman, M. S., \& Pavlou, P. A. (2003). Predicting e-services adoption: a perceived risk facets perspective. International Journal Human-Computer Studies, 59(4), 451-474.

[22] Johnson, M. S., Sivadas, E., \& Garbarino, E. (2008). Customer satisfaction, perceived risk and affective commitment: an investigation of directions of influence. Journal of Services Marketing, 22(5), 353362.

[23] Sohn, S. (2017). A contextual perspective on consumers' perceived usefulness: The case of mobile online shopping. Journal of Retailing and Consumer Services, 38, 22-33.

[24] Hung, M.-C., Hwang, H.-G., \& Hsieh, T.-C. (2007). An exploratory study on the continuance of mobile commerce: an extended expectation-confirmation model of information system use. International Journal of Mobile Communications, 5(4), 409-422.

[25] Yuan, S., Liu, Y., Yao, R., and Liu, J. (2014). An investigation of users' continuance intention towards mobile banking in China. Information Development, 32(1) 20-34.

[26] Devaraj, F., Fan, M., \& Kohli, R. (2002). Antecedents of B2C channel satisfaction and preference: validating ecommerce metrics. Information System Research, 13(3), 316-333.

[27] Rogers, E. M., (1983). Diffusion of innovations. Simon and Schuster.

[28] Wang, Y. S., \& Liao, Y. W. (2008) .Understanding individual adoption of mobile booking services: an empirical Investigation. Cyber Psychology \& Behavior, 1(5), 603-605.

[29] Low, W.-S., Lee, J.-D., \& Cheng, S.-M. (2013). The link between customer satisfaction and price sensitivity: an investigation of retailing industry in Taiwan. Journal of Retailing and Consumer Services, 20(1), $1-10$.

[30] Munnukka, J. (2008). Customers' purchase intentions as a reflection of price perception. Journal of Product and Brand Management, 17(3), 188-196.

[31] Koppius, O., Speelman, W., Stulp, O., Verhoef, B., \& Heck, E.V. (2005). Why are customers coming back to buy their airline tickets online? Theoretical explanations and empirical evidence. In Proceedings of the 7th international conference on Electronic commerce. ACM, Xi' an, China, 319-326.

[32] Park, H.-H., \& Noh, M.-J., (2012). The Influence of innovativeness and price sensitivity on purchase intention of Smart wear. Journal of the Korean Society of Clothing and Textiles. 36(2), 218-230.

[33] Davis, F. D., Bagozzi, R. P., and Warshaw, P. R. (1992). Extrinsic and Intrinsic Motivation to Use Computers in the Workplace. Journal of Applied Social Psychology, 22(4), 1111-1132.

[34] Gefen, D. (2000). E-commerce: The role of familiarity and trust. Omega: The International Journal of Management Science, 28(6), 725737.

[35] Jarvenpaa, S. L., Tractinsky, N., and Vitale, M. (2000). Consumer Trust in an Internet Store. Information Technology and Management, 1, 4571.

[36] Malhotra, N. K. (2010). Marketing Reseach : An Applied Orientation, $6^{\text {th }}$ ed. Pearson Education.

[37] Hair, J. F., Black, W. C., Babin, B. J., and Anderson, R. E. (2010). Multivariate Data Analysis, $7^{\text {th }}$ ed, Pearson Prentice Hall.

[38] Yuan, S., Liu, Y., Yao, R., \& Liu, J. (2014). An investigation of users continuance intention towards mobile banking in China. Information Development, 32(1), 20-34. 
[39] Tan, K. S., Chong, S. C., Loh, P. L., \& Lin, B. (2010). An evaluation of e-banking and m-banking adoption factors and preference in Malaysia: a case study. International Journal of Mobile Communications, 8(5), 507-527.

[40] Aldás-Manzano, J., Lassala-Navarré, C., Ruiz-Mafé, C., \& Sanz-Blas, S. (2009). The role of consumer innovativeness and perceived risk in online banking usage. International Journal of Bank Marketing, 27(1), 53-75.
[41] Agarwal, R., \& Prasad, J. (1998). A conceptual and operational definition of personal innovativeness in the domain of information technology. Information Systems Research, 9(2), 204-215.

[42] Viva.co.id. (2017). E-commerce di Indonesia Cenderung Perang Harga. Retrieved from: https://www.viva.co.id/digital/digilife/ 986764-e-commerce-di-indonesia-cenderung-perang-harga. 


\section{APPENDIX}

\section{ITEMS OF MEASUREMENT}

\begin{tabular}{|c|c|c|}
\hline Variables & Definition & Item \\
\hline \multirow{5}{*}{ Perceived Risk } & \multirow{5}{*}{$\begin{array}{l}\text { Uncertainty in the possibility of negative } \\
\text { consequences in using a product or } \\
\text { service (Featherman \& Pavlou, 2003). }\end{array}$} & $\begin{array}{l}\text { I'm afraid the payment system in the Shopee application is not perfect (e.g. double } \\
\text { counting, unsuccessful transactions, etc.). }\end{array}$ \\
\hline & & $\begin{array}{l}\text { I'm concerned that the Shopee application system is not reliable in processing } \\
\text { payments (e.g. system errors, unstable connection when accessing application, etc.) }\end{array}$ \\
\hline & & My personal data is not well protected in the Shopee application. \\
\hline & & $\begin{array}{l}\text { I think internet hackers may be misusing my personal data when I shop at Shopee } \\
\text { application. }\end{array}$ \\
\hline & & $\begin{array}{l}\text { My decision to shop at Shopee application involves a higher risk (e.g. performance, } \\
\text { time, financial, psychological, and security risks) }\end{array}$ \\
\hline \multirow{6}{*}{ Perceived Usefulness } & \multirow{6}{*}{$\begin{array}{l}\text { Belief related to the benefits of the } \\
\text { system to improve performance (Davis, } \\
\text { 1989) }\end{array}$} & I am greatly facilitated in finding products using the Shopee application. \\
\hline & & I am greatly facilitated in choosing products using the Shopee application. \\
\hline & & I can complete the shopping transaction faster by using the Shopee application. \\
\hline & & I can save my energy while shopping by using the Shopee application. \\
\hline & & I can easily find the desired product in the Shopee application. \\
\hline & & I can shop faster by using the Shopee application. \\
\hline \multirow{4}{*}{ Perceived Ease of Use } & \multirow{4}{*}{$\begin{array}{l}\text { Individuals expectation about the effort } \\
\text { of using a system (Davis, 1989) }\end{array}$} & I can use the Shopee application easily. \\
\hline & & I can easily understand how to use the Shopee application. \\
\hline & & Overall, I believe that Shopee application is easy to use. \\
\hline & & I assume that using the Shopee application is not difficult and easy to be understood \\
\hline \multirow{3}{*}{ Perceived Enjoyment } & \multirow{3}{*}{$\begin{array}{l}\text { The degree of pleasant in using } \\
\text { technology, regardless of the } \\
\text { consequences of use that might be } \\
\text { considered (Davis et al., 1992) }\end{array}$} & I love shopping at Shopee application. \\
\hline & & I think the process of using the Shopee application is fun. \\
\hline & & I enjoy shopping at Shopee application. \\
\hline \multirow{5}{*}{ Personal Innovativeness } & \multirow{5}{*}{$\begin{array}{l}\text { A level of individual speed in adopting } \\
\text { new innovations compared to others in } \\
\text { systems (Rogers, 1983) }\end{array}$} & $\begin{array}{l}\text { If I hear about there is new mobile shopping application, I will will try it (e.g. } \\
\text { downloading it, trying from someone else's device, etc.). }\end{array}$ \\
\hline & & I'm usually the first to try new mobile shopping applications among my friends. \\
\hline & & In general, I do not hesitate to try new mobile shopping applications. \\
\hline & & I love to try new mobile shopping applications. \\
\hline & & I do not hesitate to shop at the Shopee application even if my friends do not use it. \\
\hline \multirow{4}{*}{ Satisfaction } & \multirow{4}{*}{$\begin{array}{l}\text { A pleasant or positive emotional state as } \\
\text { a result of a technological system } \\
\text { performance (Locke, 1976) }\end{array}$} & I am satisfied with my decision to shop at Shopee application. \\
\hline & & I consider my choice to shop at the Shopee application is a wise decision. \\
\hline & & In general, I'm happy with my decision to shop at the Shopee application. \\
\hline & & My experience in shopping at the Shopee application is very satisfying. \\
\hline \multirow{4}{*}{ Repurchase Intention } & \multirow{4}{*}{$\begin{array}{l}\text { The subjective possibility of consumers } \\
\text { to revisit an online store (Wu et al., } \\
\text { 2014) }\end{array}$} & If I want to buy a product, I might buy it at the Shopee application. \\
\hline & & If I could, I will use the Shopee application for future purchases. \\
\hline & & I intend to go back to shop at Shopee application. \\
\hline & & I would like to revisit the Shopee application to purchase products in the near future. \\
\hline \multirow{5}{*}{ Price Sensitivity } & \multirow{5}{*}{$\begin{array}{l}\text { How consumers response to price and } \\
\text { price changes (Goldsmith et al., 2005) }\end{array}$} & I am reluctant to pay more to buy products on the Shopee application. \\
\hline & & I am reluctant to spend a lot of money on products in the Shopee application. \\
\hline & & $\begin{array}{l}\text { I am little reluctant to buy products in the Shopee application if the price is more } \\
\text { expensive than elsewhere. }\end{array}$ \\
\hline & & $\begin{array}{l}\text { I feel it's a problem if I know that buying products in a Shopee application will tend } \\
\text { to be more expensive. }\end{array}$ \\
\hline & & I am not willing to pay a fortune to buy products in the Shopee app. \\
\hline
\end{tabular}

